\title{
PTPN14 Gene
}

National Cancer Institute

\section{Source}

National Cancer Institute. PTPN14 Gene. NCI Thesaurus. Code C125447.

This gene is involved in protein dephosphorylation, cell migration, cell adhesion and lymphangiogenesis. 